\title{
Examining Epistemological Views of Engineering among First-Year Engi- neering Students
}

\section{Prof. Yang Yang, Kansas State University}

Yang Lydia Yang is Assistant Professor of Quantitative Research Methodology at College of Education, Kansas State University. She received her Ph.D. in Curriculum \& Instruction from Florida International University. Her research interest include quantitative research design, retention and advancement of women in STEM fields, motivation and self-regulated learning. 


\title{
Examining Students' Epistemological Views of Engineering among
}

\author{
First Year Engineering Students
}

\section{Introduction}

The research interest in engineering epistemology has been growing as more engineering education researchers consider that students' beliefs about the nature of engineering is essential to how they learn, which influences their professional preparation [1]. In a report written by the Steering Committee of National Engineering Education Research Colloquies [1], engineering epistemology was one of the key research areas for the new discipline of engineering education.

Epistemology refers to how individuals view the nature of knowledge and knowing in a particular domain [2]. Since epistemology was first introduced by Perry [3], several frameworks and models were subsequently developed to capture and refine the complexity of this concept [2], [4], [5]. While these models have framed epistemological beliefs in somehow different ways [2], they all propose that multiple dimensions should be considered when understanding epistemological beliefs. These dimensions include a) certainty of knowledge, the extent to which the knowledge is considered as fixed or fluid, b) simplicity of knowledge, the extent to which the knowledge is viewed as discrete or relative/contextual, c) source of knowledge, the extent to which someone is being a receiver or constructor of knowledge, d) justification for knowing, the extent to which someone justifies knowledge through evidence or authority, and e) attainability of truth, the extent to which truth is considered obtainable [6].

Students' epistemological views have been found to influence their motivations, the learning goals they set, their learning strategies, and their improvement in problem-solving processes, and learning outcomes [5] - [9]. For example, Prosser, Trigwell, Hazel, and Waterhouse [7] found that learning science concepts can be affected by epistemological beliefs. Lising and Elby [9] demonstrated that student epistemological stance has a direct influence on physics learning in a reformed introductory college physics course. Schommer [5] also found that certain personal epistemological beliefs directly predict students' comprehension in various content domains.

In engineering education, a growing number of research has examined students' epistemological views in engineering learning [10] - [14]. For example, Felder and Brent [10] have found that student who demonstrate higher levels of epistemological development tend to display expert engineers' thinking patterns. Liu and Zhu [11] found that project-based learning positively influence students' contextual constructivist thinking. Frye, Montfort, and Brown [12] reported that as students' epistemological views change, their ability to perform critical evaluation of the reasoning for engineering processes tend to progress as they advance in the academic program. 


\section{Research Objectives}

The purpose of this study is to examine the multidimensionality of engineering epistemological beliefs among first year engineering students. The first objective of this study is to explore the engineering epistemological beliefs among students in introductory engineering courses, using a unique methodological approach, Q methodology. The second objective is to examine whether such epistemological beliefs are related to student academic outcomes among first year engineering students.

This study focuses on students in introductory engineering courses for two reasons. First, introductory STEM (including engineering) courses are often large, posing difficulties for instructors and students to closely examine and discuss concepts and knowledge covered in the courses. Students' epistemological views in these courses can be potentially used to relate to students' course performances, which could ultimately benefit student learning and academic success.

Second, introductory engineering courses are mostly offered in the first year of college, a transitional period when young adults often make important major-related and future careerrelated decisions, according to both emerging adulthood literature [15] and first-year experience literature [16]. However, several reports from the American Society for Engineering Education [17] and the National Center for Educational Statistics [18] conclude that first year is also when attrition rate in engineering (as well as in many other STEM majors) is particularly high. Close examination of student epistemological views in introductory engineering courses allows educators to better understand students' perceptions toward engineering and potentially adjust teaching strategies and approaches to address students' needs and concerns in the classes [19]. Such experience during transitional years may play a key role in students' decisions of staying in engineering.

\section{Methodology}

\section{Q Methodology}

$\mathrm{Q}$ is a means to systematically measure subjectivity and it is more aligned with qualitative paradigm [20]. It enables researchers to explore different perspectives, preferences, or behaviors among people on a given topic. In a Q study, participants typically are instructed to perform Qsorting process on a set of items/statements of the topic under investigation [21]. Individuals are required to judge each statement item in relation to other items drawing on their own experiences regarding the topic of interest, in this case, learning and understanding engineering in introductory courses. Participants are instructed to initially sort all the statements into three piles 
based on their agreement or disagreement with the statements, like my view of the nature of engineering, neutral, and unlike my view of the nature of engineering. Participants then distribute the statements, each on a separate strip of paper, on the forced distribution grid similar to the one shown below (Figure 1). Once participants are satisfied with their statement distribution, they record the statement numbers in the grid. The complete sort essentially reflects a participant's subjectivity of the topic, which is intrinsically qualitative [20,22].

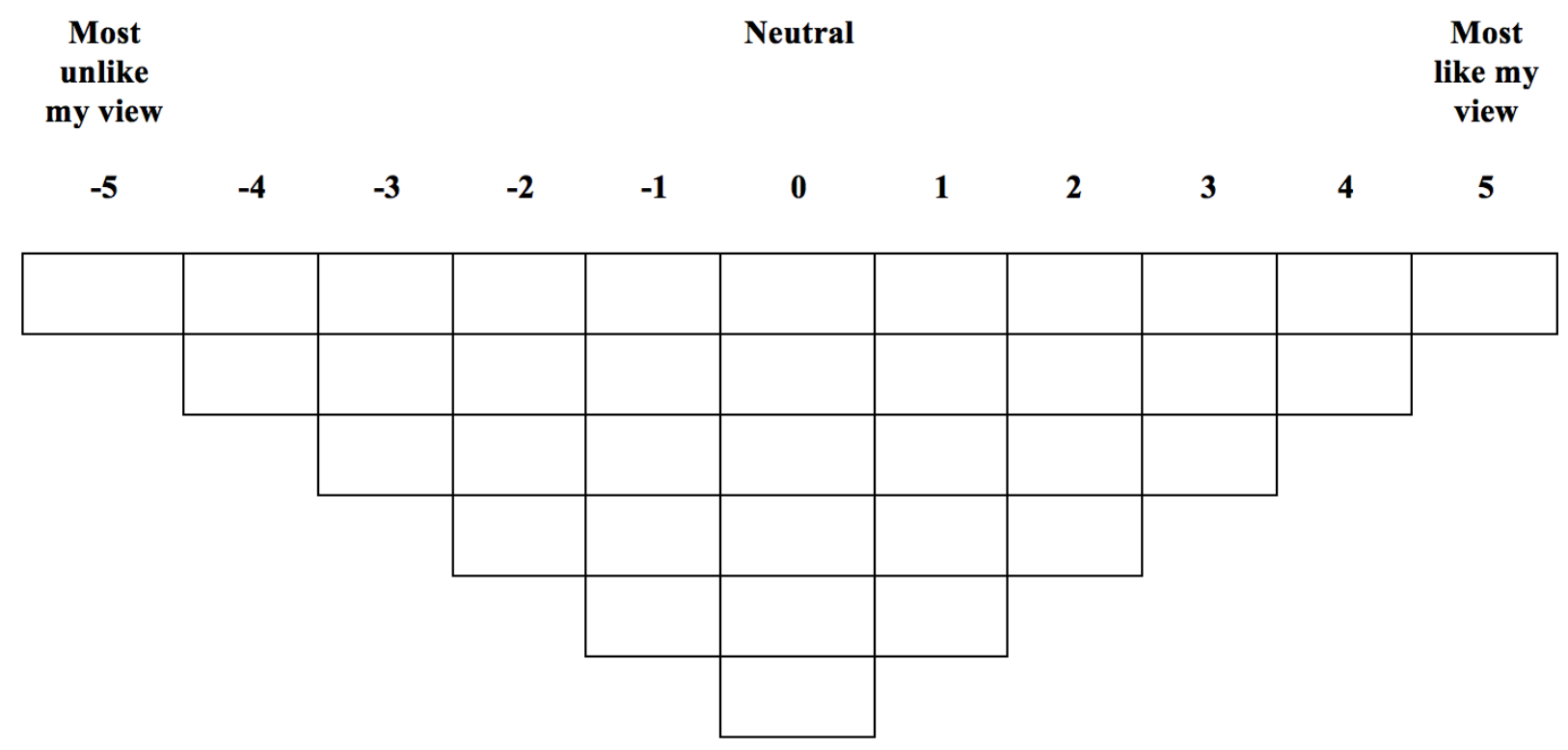

Figure 1. Sorting grid with one unique statement number placed in each cell.

Once the Q-sorting process is completed, the Q-sort data is analyzed through a series of sophisticated statistical procedures including correlation, factor analysis and calculation of factor scores [20]. The results reveal an individual's responses/views on the topic and the extent to which this person's view is shared by other individuals [23]. Individuals with a similar pattern of responses on the issue are categorized into a typical group, also known as a $\mathrm{Q}$ factor [21]. Each $\mathrm{Q}$ factor represents a unique perspective shared by the individuals who sort the statements in a similar way.

It is worth mentioning that Q methodology correlates participants to explore the patterns among them. Therefore, $\mathrm{Q}$ studies typically utilize small sample sizes and it is psychometrically acceptable [20,23].

\section{Participants and Procedures}

This study was conducted at a large Midwestern land grant university. With the approval of University Institutional Review Board, prior to the beginning of the fall semester, the researcher 
contacted instructors of introductory engineering courses for permission to visit their classes. Given instructors' permission, students were recruited by the researcher on the first day of classes. Interested students were directed to a confidential online survey to set up a time for participating in the study in person. Because of the complexity of the Q-sorting process and the amount of time involved, each participant came into a small group session at his/her convenience to complete to study. During each small session, the researcher first explained the purpose of the study and read a consent statement. For students who agreed to participate, the researcher guided them to complete the Q-sorting process as well as a brief demographic survey. It took participants approximately $30-40$ minutes to complete the entire session. The results presented below were based on the completed responses from 19 students from an introductory engineering course in College of Engineering.

\section{Measures}

Epistemological Beliefs Survey for Mathematics developed by Wheeler [22] was adapted to measure student engineering epistemological beliefs. The measure contains six underlying factors: Innate ability to learn $(\alpha=.83)$, structure of knowledge $(\alpha=.65)$, certainty of knowledge $(\alpha=.63)$, speed of knowledge acquisition $(\alpha=.73)$, source of knowledge $(\alpha=.65)$, and real world applicability $(\alpha=.84)$. The instrument has established good estimates of validity and reliability [24]. The wordings of the items were changed from mathematics to engineering when applicable to better reflect engineering epistemological beliefs. A total of 36 statements were included in the sample for Q-sorting. To further examine the relationship between epistemological beliefs and academic outcomes, students' cumulative GPAs (on a 4-point scale) and the degree programs they were pursuing one year later were retrieved from the University Registrar's Office, with participant consent.

\section{Results}

PQMethod program was used for all statistical analyses [25]. The analyses included Q factor analysis and computation of $\mathrm{Q}$ factor scores. A principal components factor analysis with varimax rotation was first conducted. This step intended to extract underlying factors in the data and maximize the loadings of as many items as possible on one or more of the factors [23]. The $\mathrm{Q}$ factors were generated from $\mathrm{Q}$ factor analysis. Each $\mathrm{Q}$ factor represented a particular type of epistemological views shared by participants who responded to statements in a similar way. Then each participant was assigned a factor loading value on each factor ranging from -1 to 1 , which indicated the magnitude of association between a person's response and the underlying factor. Based upon the participant factor loadings, "defining respondents" can be identified. These were the respondents who loaded strongly on a factor and thus characterized that factor [21]. The defining participants' responses scores across different items in the instrument were averaged to 
create a factor score for each item [23]. PQMethod automatically normalizes factor scores into $z$-scores, which are use to understand the main characteristics of each profile type. Furthermore, the $z$-scores of the statements are utilized to compare the differences among various profile types.

Table 1. Four-factor Solution with Number of Defining Respondents

\begin{tabular}{lcccc}
\hline Characteristic & Factor 1 & Factor 2 & Factor 3 & Factor 4 \\
& & & & \\
\hline Number of Definers & 6 & 2 & 5 & 2 \\
$\begin{array}{l}\text { Percent of Variation } \\
\text { Explained }\end{array}$ & $23 \%$ & $15 \%$ & $22 \%$ & $13 \%$ \\
\hline
\end{tabular}

Each $\mathrm{Q}$ factor generated from factor analysis represented a unique type of epistemological view. Four $\mathrm{Q}$ factors, in other words, four different epistemological views emerged from the analyses. Table 1 shows the number of defining respondents for each factor. The epistemological view represented by the first factor had six students loaded on it, with $23 \%$ variance explained. Two students shared the second view (15\% variance explained). The third view (22\% variance explained) had five students loaded on it. The fourth view (13\% variance explained) was shared by two students.

After identifying four different epistemological views, the following section focused on the key characteristics of each epistemological view. This was done through examining participants' responses on instrument statements, specifically, the statements ranked the highest or the lowest on each factor. These statements are known as "extremely ranked" statements, with either very high or very low z-scores. They represented the main characteristics of a particular point of view shared by respondents.

Table 2 below shows the extremely ranked statements with high positive z-scores $(z \geq 1.00$, representing most like my view) and high negative z-scores $(z \leq-1.00$, representing least like my view) among the respondents who shared the first epistemological view (Factor 1). The students who shared the first view were cognizant of their own understanding of the materials in class. They learned engineering best when watching the teacher work a problem. This suggested they were likely to consider knowledge to reside in an authoritative source such as teachers or textbooks. These students expressed frustration when they did not know how to solve an engineering problem immediately. But they believed in their own ability in learning engineering and the knowledge/truth in engineering to be fluid instead of fixed. 
Table 2. Factor 1 Extreme Statements with High and Low Z-scores

\begin{tabular}{clc}
\hline No. & \multicolumn{1}{c}{ Statement } & \multicolumn{1}{c}{$z$-score } \\
\hline 21 & I can tell when I understand the materials in this class. \\
20 & $\begin{array}{l}\text { I learn engineering best when watching the teacher work example } \\
\text { problems. }\end{array}$ & 1.88 \\
33 & $\begin{array}{l}\text { When I don't understand something in this class, I try to figure it out } \\
\text { myself. }\end{array}$ & 1.26 \\
26 & $\begin{array}{l}\text { It is frustrating to read an engineering problem and not know immediately } \\
\text { how to begin to solve it. }\end{array}$ & 1.15 \\
& & \\
13 & $\begin{array}{l}\text { Engineering is like a foreign language to me and even if I work hard, I'll } \\
\text { never really get it. }\end{array}$ & -1.20 \\
35 & Truth is unchanging in engineering. & -1.70 \\
23 & I'm just not an engineering person. & -1.71 \\
\hline
\end{tabular}

The second view, Factor 2, was characterized by a coherent view of engineering as seeing the ideas and concepts in engineering to be interconnected (Table 3). They acknowledged that practicing many engineering problems was necessary regardless of how smart a student was. These students had to be taught the right way in order to solve engineering problems; and when they were showed multiple ways to answer or solve an engineering problem, they found it confusing. This suggested that students tended to have naïve view of treating knowledge as discrete isolated bits.

Table 3. Factor 2 Extreme Statements with High and Low Z-scores

\begin{tabular}{|c|c|c|}
\hline No. & Statement & $z$-score \\
\hline 29 & $\begin{array}{l}\text { I see the ideas and concepts of engineering as coherent and } \\
\text { interconnected. }\end{array}$ & 1.81 \\
\hline 2 & To solve engineering problems, I have to be taught the right procedure. & 1.36 \\
\hline 21 & I can tell when I understand the materials in this class. & 1.36 \\
\hline 12 & $\begin{array}{l}\text { I find it confusing when my instructor shows more than one way to work } \\
\text { a problem. }\end{array}$ & 1.21 \\
\hline 19 & I will rarely use engineering knowledge I've learned in real life. & -1.06 \\
\hline 13 & $\begin{array}{l}\text { Engineering is like a foreign language to me and even if I work hard, I'll } \\
\text { never really get it. }\end{array}$ & -1.66 \\
\hline 30 & $\begin{array}{l}\text { The smartest students don't have to practice many engineering problems } \\
\text { because they just get it. }\end{array}$ & -1.81 \\
\hline 27 & Creativity has no place in an engineering class. & -2.12 \\
\hline
\end{tabular}

Unlike the second view, students who shared the third view, Factor 3, preferred learning multiple ways to answer or solve an engineering problem (Table 4). They valued the ambiguity of 
knowledge in that answers are not simply either right or wrong in engineering. The third view emphasized the importance of knowing why something works in engineering rather than memorizing a formula. This suggested a more sophisticated view of understanding of knowledge as interrelated concepts. Furthermore, these students saw the connections between what they learned in engineering class and real world applications.

Table 4. Factor 3 Extreme Statements with High and Low Z-scores

\begin{tabular}{|c|c|c|}
\hline No. & Statement & $z$-score \\
\hline 22 & $\begin{array}{l}\text { It is important to know why something works rather than memorize a } \\
\text { formula. }\end{array}$ & 1.88 \\
\hline 31 & $\begin{array}{l}\text { I can see the connections between what I have learned in class and real } \\
\text { world applications. }\end{array}$ & 1.51 \\
\hline 3 & $\begin{array}{l}\text { When I encounter a difficult engineering problem, I stick with it until I } \\
\text { solve it. }\end{array}$ & 1.39 \\
\hline 29 & $\begin{array}{l}\text { I see the ideas and concepts of engineering as coherent and } \\
\text { interconnected. }\end{array}$ & 1.32 \\
\hline 16 & Engineering helps us better understand the world we live in. & 1.26 \\
\hline 19 & I will rarely use engineering knowledge I've learned in real life. & -1.44 \\
\hline 4 & $\begin{array}{l}\text { I don't care about why something works, just show me how to solve the } \\
\text { problem. }\end{array}$ & -1.70 \\
\hline 27 & Creativity has no place in an engineering class. & -2.15 \\
\hline
\end{tabular}

Table 5. Factor 4 Extreme Statements with High and Low Z-scores

\begin{tabular}{rlc}
\hline No. & \multicolumn{1}{c}{ Statement } & $z$-score \\
\hline 22 & $\begin{array}{l}\text { It is important to know why something works rather than memorize a } \\
\text { formula. }\end{array}$ & 1.81 \\
20 & $\begin{array}{l}\text { I learn engineering best when watching the teacher work example } \\
\text { problems. }\end{array}$ & 1.36 \\
6 & $\begin{array}{l}\text { Sometimes I just have to accept answers from my instructor even though I } \\
\text { don't understand them. }\end{array}$ & 1.36 \\
19 & $\begin{array}{l}\text { I will rarely use engineering knowledge I've learned in real life. } \\
34\end{array}$ & $\begin{array}{l}\text { I can learn new things, but I can't really change the engineering ability I } \\
\text { was born with. }\end{array}$ \\
& $\begin{array}{l}\text { If I can't solve an engineering problem quickly, I get frustrated and tend to } \\
\text { give up. }\end{array}$ & -1.23 \\
\end{tabular}

The fourth view, Factor 4, similar to the third view, emphasized the importance of knowing why something works rather than memorizing a formula (Table 5). However, students holding this view considered answers to be either right or wrong in engineering; even though they didn't understand them, they had to accept answers from the instructor sometimes. These students 
learned engineering best when watching the teacher work a problem. Together it suggested they were likely to consider knowledge to reside in an authoritative source such as teachers or textbooks.

The relationship between epistemological views and student academic outcomes was further examined through students' GPAs on a 4-point scale one year later and whether they stayed in an engineering degree program one year later (Table 6). Two students who shared the fourth view and one out of six students who held the first view have left engineering one year later while all others were retained. Among those who were retained, students who held the second view had the highest average GPAs one year later $(\mathrm{m}=3.68)$, followed by the third view $(\mathrm{m}=3.41)$. Students who held the first view seemed to struggle academically with lower GPAs $(\mathrm{m}=2.7)$.

Table 6. Percentage and Average Cumulative GPA of Students Retained by Factors

\begin{tabular}{lcccc}
\hline & Factor 1 & Factor 2 & Factor 3 & Factor 4 \\
\hline Percentage of Students Retained & $83.3 \%$ & $100 \%$ & $100 \%$ & $0 \%$ \\
Average Cumulative GPA of Students & 2.7 & 3.68 & 3.41 & N/A \\
Retained & & & & \\
\hline
\end{tabular}

\section{Discussions}

This paper examined engineering epistemological beliefs among first year college students in an introductory engineering course. A unique approach, Q methodology, was utilized to explore various epistemological views of engineering among students. Q methodology does not generalize across instrument items, the typical statistical approach used in social science. Instead, Q compares and identifies typologies based on individuals' systematic point of view regarding engineering epistemology reflected by forced Q-sorting procedure.

Equipped with Q, this study revealed four distinct engineering epistemological views. Students across epistemological views differed in three areas, speed of knowledge acquisition, simplicity of knowledge, and source of knowledge. Such distinctions are largely supported by the literature $[6,22]$. It seems those who held the first view tended to give up quickly if they did not know how to solve an engineering problem quickly. Students shared the first view and the four view considered knowledge to reside in an authoritative source such as teachers or textbooks rather than being a process that everyone is capable of doing, given enough practices. Such epistemological views on engineering may be related to their academic struggles. Students who held the third view showed a more sophisticated view of understanding of knowledge as interrelated rather than isolated concepts. 
This study allowed the researchers to have a nuanced understanding of various engineering epistemological views held by first year college students in an introductory engineering course. One limitation of the study is that this study was correlational in nature in the sense that student epistemological views were naturally occurring in a college environment and were unethical to manipulate. Nevertheless, understanding the complexity of epistemological beliefs and perspectives among first year engineering students could be helpful in improving students' learning of engineering. The findings can potentially enable educators to better understand students' perceptions toward engineering and adjust teaching strategies and approaches to address students' needs and concerns in the classes. 


\section{References}

[1] The Steering Committee of National Engineering Education Research Colloquies, "Special report: The research agenda for the new discipline of engineering education," Journal of Engineering Education, vol. 95, pp. 259-261, 2006.

[2] B. K. Hofer and P. R. Pintrich, "The development of epistemological theories: Beliefs about knowledge and knowing and their relation to learning," Review of Educational Research, vol. 67, pp. 88-140, 1997.

[3] W. G. Perry, Forms of Intellectual and Ethical Development in the College Years: A Scheme. New York: Holt, Rinehart and Winston, 1970.

[4] P. M. King \& K. S. Kitchener, The Development of Reflective Judgment: Understanding and Promoting Intellectual Growth and Critical Thinking in Adolescents and Adults. San Francisco: Jossey-Bass, 1994.

[5] M. Schommer, "Effects of beliefs about the nature of knowledge on comprehension," Journal of Educational Psychology, vol. 82, pp. 498-504, 1990.

[6] B. Hofer, "Exploring the dimensions of personal epistemology in differing classroom contexts: Student interpretations during the first year of college," Contemporary Educational Psychology, vol. 29, pp. 129-163, 2004.

[7] M. Prosser, K. Trigwell, E. Hazel, and F. Waterhouse, "Students' experiences of studying physics concepts: The effects of disintegrated perceptions and approaches," European Journal of Psychology of Education, vol. 15, pp. 61-74, 2000.

[8] S. Ramlo, "Student views of learning in a first semester college physics course: A study using Q methodology," Operant Subjectivity, vol. 30, pp. 52-63, 2008.

[9] L. Lising and A. Elby, "The impact of epistemology on learning: A case study from introductory physics," American Journal of Physics, vol. 73, pp. 372-382, 2005.

[10] R. M. Felder and R. Brent, "The intellectual development of science and engineering students. Part 2: Teaching to promote growth,” Journal of Engineering Education, vol. 93, pp. 279-291, 2004. 
[11] R. Liu and J. Zhu, "Personal epistemology: The impact of project-based learning," Proceedings of the American Society for Engineering Education Annual Conference, June 2018, Salt Lake City, UT.

[12] N. L. Frye, D. Montfort, and S. A. Brown, "Personal epistemology and sophomore civil engineering students," Proceedings of the American Society for Engineering Education Annual Conference, June 2013, Atlanta, GA.

[13] J. A. Greene, J. Torney-Purta, and R. Azevedo, "Empirical evidence regarding relations among a model of epistemic and ontological cognition, academic performance, and educational level," Journal of Educational Psychology, vol. 102, pp. 234-255, 2010.

[14] M. Schommer-Aikins, "Explaining the epistemological belief system: Introducing the embedded systemic model and coordinated research approach," Educational Psychologist, vol. 39, pp. 19-29, 2004.

[15] B. W. Roberts and R. W. Robins, "Broad dispositions, broad aspirations: The intersection of personality traits and major life goals," Personality and Social Psychology Bulletin, vol. 26, pp. 1284-1296, 2000.

[16] K. Krause and H. Coates, "Students' engagement in first-year university," Assessment and Evaluation in Higher Education, vol. 33, pp. 493-505, 2008.

[17] American Society for Engineering Education, "Engineering by the Numbers: ASEE Retention and Time-to-Graduation Benchmarks for Undergraduate Engineering Schools, Departments and Programs, "Washington, DC. 2016.

[18] National Center for Education Statistics, "STEM in Postsecondary Education: Entrance, Attrition, and Coursetaking Among 2003-2004 Beginning Postsecondary Students, "NCES 2013-152. Washington, DC. 2012.

[19] D. Hammer, "Discovery learning and discovery teaching," Cognition \& Instruction, vol. 15, pp. 485-529, 1997.

[20] S. R. Brown, Political Subjectivity. New Haven, CT: Yale University Press, 1980.

[21] Y. Yang, "A brief introduction to Q methodology," International Journal of Adult Vocational Education and Technology, vol. 7, pp. 42-54, 2016. 
[22] S. Ramlo and I. Newman, "Q methodology and its position in the mixed methods continuum," Operant Subjectivity, vol. 34, pp. 173-192, 2011.

[23] B. McKeown and D. B. Thomas, Q Methodology. (Quantitative Applications in the Social Sciences, Vol. 66). Newbury Park, CA: Sage, 1988.

[24] D. W. Wheeler, The development and construct validation of the Epistemological Beliefs Survey for Mathematics (Doctoral dissertation, Oklahoma State University), 2007.

[25] P.Schmolck, PQMethod Manual. Retrieved from

http://schmolck.userweb.mwn.de/qmethod/pqmanual.htm, 2014. 